\title{
Effects on Primary School Teacher Candidates of Developing and Implementing Jigsaw Technique Activities Enriched with Educational Games in Science and Technology Teaching Lessons
}

\author{
Filiz, Avcl* \\ Received: October 6, 2020; received in revised form: February 19, 2021; \\ accepted: February 22, 2021.
}

\begin{abstract}
:
Introduction: The aim of the study was to examine the effects on Primary School Teacher Candidates of developing and implementing jigsaw technique activities enriched with educational games in Science and Technology Teaching lessons.

Methods: In the study, the mixed design was used. The single group pretest post-test weak experimental pattern from among quantitative research methods and a case study from among qualitative research methods were used. The study group consisted of 48 teacher candidates continuing their education at Istanbul University, in the Primary Education Department Classroom Teaching Program during the 2018-2019 academic year. In the Science and Technology II lessons the "Jigsaw technique enriched with educational games" was implemented. The "Communication Skills Scale" and the "Opinion Form Jigsaw Technique Enriched with Educational Games" (JTEEG) were used as data collection tools. The SPSS 16 program and the content analysis method were used for data analysis.

Results: When the quantitative data obtained from the study were examined, it was determined that there were statistically significant differences between the pre-test and post-test mean scores of the communication skills scale in favor of the post-test. Based on the qualitative findings of the study, teacher candidates stated opinions including the themes of "Positive Opinions", "Negative Opinions", and "Preferring the Technique "and" Suggestions for technique related changes". It was also observed that the majority of the teacher candidates indicated positive opinions.

Discussion: It is important that teacher candidates who will be educating students in the future develop their skill levels in order to improve the communication skills of their students. As can be understood from the results of the present study, JTEEG is effective in developing the communication skills of classroom teacher candidates. Also, it is very
\end{abstract}

\footnotetext{
* Filiz Avcı, Istanbul University-Cerrahpaşa, Hasan Ali Yücel Faculty of Education, Istanbul, Turkey; filizfen@istanbul.edu.tr
} 


\title{
Acta Educationis Generalis \\ Volume 12, 2022, Issue 1
}

\begin{abstract}
important that the classroom teachers who will teach a science lesson for the first time increase the interest of the class making sure that the students enjoy science. It can be put forth, based on the findings of the study that JTEEG is quite effective in making students like a science lesson and learn through enjoyment.
\end{abstract}

Limitations: There were several limitations to this study. The first limitation was that this research relied on only Primary School Teacher Candidates' data. The second limitation was the subject. The study was carried out only on the "Properties of Matter" unit. The third limitation was that the study data were only collected in Turkey, and so, the study results are only regionally generalizable.

Conclusion: In conclusion, it was observed as a result of the present study on the impacts of developing JTEEG related activities and implementing them that the technique used in this study resulted in an increase in the communication skill levels of teacher candidates. As can be understood from the results of the present study, JTEEG is effective in developing the communication skills of classroom teacher candidates. Hence, it can be suggested in the light of the findings of this study that education environments should be arranged based on JTEEG. Also, it can be stated, based on the statements of the teacher candidates, that they mostly have positive opinions on the implemented technique. Science lessons are among the lessons that students mostly approach with concern. The fact that it involves abstract concepts and that some of its subjects are perceived as difficult are among the reasons for this concern. Students get to take a science lesson for the first time in the 3rd grade. It is very important that the classroom teachers who will teach the science lesson for the first time increase the interest of the class by making sure that the students enjoy science. It can be put forth, based on the findings of the study, that JTEEG is quite effective in making children like the science lessons and learn through enjoyment, since it enables them to be more active, take responsibility while providing them with the opportunity to develop new games and activities, establish more communication with other students in addition to making abstract concepts more concrete. For this reason, it is very important that the techniques to be applied are learned and applied by the teacher candidates.

Key words: primary school teacher candidates, Jigsaw technique, educational games, science and technology teaching.

\section{Introduction}

Today, the importance of science education increases with the developments in science and technology. National and international societies are striving to improve the quality of their science education in order to adapt to advancements (Çepni, 2011). In general, recent educational reforms place importance on reflecting the concept of scientific literacy in the educational program. In this 


\section{Acta Educationis Generalis \\ Volume 12, 2022, Issue 1}

regard, education programs aim to raise individuals who understand the relationship between science, technology and society, who can use the information they learn in solving the problems they encounter, and who have advanced questioning skills and communication skills. Raising science literate individuals with these characteristics puts forth the necessity of having a sufficient level of knowledge in science literacy along with sufficient experience in implementing the teaching methods and techniques for teachers who will teach the science lessons. Teachers' lack of knowledge and misconceptions about some science subjects (Atwood \& Atwood, 1996; Çepni, Küçük, \& Ayvac1, 2003) indicate the importance of teaching teacher candidates about Science and Technology Teaching.

The last science-related courses taken by Primary School teacher candidates are Science and Technology Teaching I-II. While the Science and Technology Teaching I lessons include the attributes of the scientific method, the aims of science teaching, the constructivist approach and science learning, scientific process skills and exemplary applications, Science and Technology Teaching II lessons include the development of sample activities on the basis of the science and technology teaching program using various teaching models, and traditional and alternative assessment and evaluation techniques (HEC, 2007-5). Primary School teacher candidates are considered to have sufficient proficiency to effectively apply the primary school science teaching program when they complete these lessons successfully. Hence, it is apparent that implementing the lessons effectively plays a vital role on learning. Even though students encounter science lessons for the first time in the preschool period, officially, the first science lessons are applied at the 3rd grade level of primary education. It will be possible for Primary School teachers, who will apply the primary school 3rd grade science lessons, to provide students with science literacy skills through the applied science and technology teaching lessons offered at the university. This can only be possible by implementing the active learning methods and techniques that place the students at the center. In the science curriculum (3rd8th grade), emphasis is placed on conducting classes in learning environments where student-based active learning approaches, such as problem-based learning, project-based learning and collaborative learning methods are applied (MOE, 2018). For this purpose, it is very important that the Primary School teacher candidates, who will teach the 3rd and the 4th grade science lessons, have sufficient knowledge of active learning approaches and are able to implement them properly.

Cooperative learning, which is one of the active learning approaches, is defined as a learning process in which students in heterogeneous groups of 3-7 people help each other learn to achieve a common goal, engage in learning activities together and motivate the group's achievements with rewards (Slavin, 1980; Senemoğlu, 2010). It has been put forth by researchers, as a result of national and international studies, that the cooperative learning method enables 


\section{Acta Educationis Generalis \\ Volume 12, 2022, Issue 1}

meaningful learning and the permanence of the acquired knowledge (Nakipoğlu, 2001), the development of critical thinking, team building, problem-solving skills (Henderson \& Martin, 2002), approach the opinions of others with tolerance, making the learning and teaching environment more enjoyable (Senemoğlu, 2010), increasing academic success and motivation (Sharan, 1980; Senemoğlu, 2010), developing empathy skills (Cohen, 1986), learning to accept different opinions, increasing emotional communication between the students and developing communication skills (Abu Seileek, 2012; Bayrakçeken, Doymuş, \& Doğan, 2015), increasing self-confidence (Slavin, 2014) and developing leadership skills (Ün Açıkgöz, 2008).

Cooperative learning methods are implemented through the use of many different techniques. Learning together (Johnson \& Johnson, 1991), student teams-achievement divisions (Slavin, 1990), team-game tournament (DeVries \& Edwards, 1974), group investigation (Sharan \& Hertz-Lazarowitz, 1980) and jigsaw (Aronson, Blaney, Stephan, Sikes, \& Snapp, 1978) are among the most frequently used learning techniques.

The jigsaw method that was first implemented by Aronson et al. (1978) was used in the present study since it enables the development of positive relations between the individuals, active participation to the process during which the individuals are able to learn from each other and are able to use many social skills, such as communication skills (Bayrakçeken, Doymuş, \& Doğan, 2015; Şimşek, 2007). The implementation process for the technique can be summarized as the formation of heterogeneous groups, formation of expert groups, each specialized in different subjects, with the participation of at least one member from the groups, the group members specializing in the expert groups returning back to their main groups to teach the subject to their friends in the group and ensuring that all subjects are learned by all class members through interaction, and finally, the assessment of group members. Each group member takes on the roles of both teacher and student in this technique (Turaçoğlu, 2009). Various changes have been made over time in the implementation of the Jigsaw technique and different forms of the technique have been developed. These are Jigsaw (Aronson et al., 1978), Jigsaw-II (Slavin, 1986), Jigsaw-III (Stahl, 1994), Jigsaw-IV (Holliday, 2000), Reverse Jigsaw (Hedeen, 2003) and Subject Jigsaw (Doymuş, 2007). Even though the basic principles of all jigsaw techniques are the same, there are small differences between them. These differences are having an exam at the end of the implementation process in Jigsaw-II technique to ensure competition in the group by rewarding successful students; assessment of the implementation process by way of standard forms in the Jigsaw-III technique; organizing an activity at the beginning of the Jigsaw IV technique to attract attention to the subject, and performing a mini-quiz at the end of all expert and main group activities; presentation of the specialized subject to all classrooms by expert groups in the Reverse Jigsaw technique, and 


\section{Acta Educationis Generalis \\ Volume 12, 2022, Issue 1}

allowing for continuous transitions between the groups as well as individual assessments in the Subject Jigsaw technique.

The aim of the Jigsaw technique (Jigsaw, Jigsaw-II, Jigsaw-III, Jigsaw-IV, Reverse Jigsaw, Subject Jigsaw) as one of the cooperative learning methods is to increase academic success in addition to raising individuals with work ethic and discipline, who are then able to work in harmony with the group, who are respectful, have empathy skills, tolerance with increased communication skills and who are sensitive to their environments. It is considered that the Jigsaw technique encourages students to cooperate, thus minimizing competition in the learning environment, encouraging students to help each other rather than to compete with each other, enabling students to develop positive attitudes towards learning by themselves and learning from each other, developing positive relations between the group members in the class, in addition to improving selfconfidence, learning and communication skills (Johnson \& Johnson, 2005; Tran $\&$ Lewis, 2012).

It has been determined, as a result of contemporary studies, that there are various studies at different educational levels regarding the effectiveness of the jigsaw technique. It is observed that the majority of the studies focus on the primary school level (Aksoy \& Gürbüz, 2012; Amedu \& Gudi 2017; Doğan, Üçar, \& Şimşek 2015; Peker \& Yalçın, 2019; Tarhan, Ayyildiz, Ogunc, \& Sesen, 2013; Timayi, Bolaji, \& Kajuru, 2015; Türkmen \& Büyükaltay, 2015; Uyanık, 2016), with a lower number of studies performed at the university level (Jansoon, Somsook, \& Coll, 2008;Turaçoğlu, 2009; Şimşek \& Baydar 2019). It is observed, when these studies are examined, that most of them focus on the impact of the technique on success and attitude. The study performed by Jansoon, Somsook and Coll (2008) on university students encompasses the research conducted via the Jigsaw IV method on the learning experiences of students in chemistry laboratories in Thailand. It was concluded as a result of the study that the students enjoyed the interactive nature of the Jigsaw IV approach and that their self-confidence levels increased since they acted as "experts" in front of their peers. A limited number of studies could be found on the impact of the jigsaw technique on communication skills (Çatalkaya, 2019; Halimah \& Sukmayadi, 2019).

Teaching through educational games is another method that encourages the active participation of the students in educational environments. Today, educational games are considered as indispensable parts of the education process. The game concept is defined differently by different researchers. According to the definition by the Turkish Language Institution (2017), the "Game" concept is defined as "entertainment with specific rules designed for improving abilities and intelligence while having a good time". Demirel (2001) defines the "Game" concept as one or more individuals taking action to reach a specific goal, either by competing or through cooperation, in accordance with certain rules. Gündüz, Aktepe, Uzunoğlu and Gündüz (2017) emphasize that 


\section{Acta Educationis Generalis \\ Volume 12, 2022, Issue 1}

games are among the most important elements that enable the social and emotional development in children. Educational games, on the other hand, are accepted as a technique that enables the gained knowledge to be repeated and reinforced in a fun way (Bayat, K1liçaslan, \& Şentürk, 2014). Demirel (2002) has put forth that educational games should be prepared and planned beforehand in order to ensure that they are not only fun but also aim towards a certain goal while also establishing a learning relationship. Educational games increase the mental activities of children through games, thereby making education more effective (Öz Pektaş, 2017). It is possible to concretize abstract concepts through games by establishing a strong relationship between theoretical learning and implementation. In this regard, it is important that games address more than one sensory organ, that they are prepared with concrete materials and that they encourage communication among students during the concretization process of abstract concepts (Kaya \& Elgün, 2015).

It is observed, when a literature survey is done, that the use of games has positive impacts on many aspects of education. The educational games used provide a positive attitude development towards learning (Akinsola \& Animasahun, 2007), increase academic performance (Kaya \& Elgün, 2015), make abstract concepts more concrete (Usta, Işık, Şahan, Genç, Taş, Gülay, Diril, Demir, \& Küçük, 2017) and understandable while making a positive contribution to the motivations of students towards the lesson (Rosas et al., 2003). Moreover, educational games can also be used to establish environments in which students can learn while having fun (Cop \& Kablan, 2018) and develop their social skills such as communication, discussion and flexibility (Berns, IslaMontes, \& Palomo-Duarte, 2016; Gonzalez \& Izquierdo, 2012; Kirriemur \& McFarlane, 2004).

There are many studies in the literature that are focused on the effectiveness of the educational games technique at different educational levels. It is observed that the majority of the studies have focused on the primary and secondary education levels (Bakker, Heuvel-Panhuizen, \& Robitzsch, 2015; Dönmez, Tekce, \& Kirmit, 2020; Kaya \& Elgül, 2015; Ören \& Avc1, 2004). The number of studies on teacher candidates and teachers is quite limited (Andic, Kadic, Grujicic, \& Malidzan, 2018; Kırbaş, 2018). Andic, Kadic, Grujicic and Malidzan (2018) carried out a study for examining the attitudes of students and teachers towards the use of educational games in the teaching process. It was observed, as a result of the study, that word associations, memory games, tangrams and quizzes are among the games that increase student motivation the most, while it was also observed that puzzles and repetitions were considered as the least interesting. On the other hand, teachers have stated that self-performed games are better than ready games since they inspire creativity in teaching.

Only one study was found on educational games that integrated cooperative learning. The study was carried out on secondary school students (Y1ldiz, Şimşek, \& Ağdaş, 2017). However, there are no studies where teacher 


\section{Acta Educationis Generalis \\ Volume 12, 2022, Issue 1}

candidates developed activities for the jigsaw technique enriched with educational games, applied and expressed their opinions, and also investigated the effect of the applied technique on communication skills. It is suggested in the MOE program, revised in 2018, to implement various active learning methods during classes. These methods can be implemented separately while it is also possible to use more than one method at different stages of the education process. With the idea that using more than one technique together will increase the effectiveness, the jigsaw technique enriched with educational games was applied in the study in order to increase the permanence in learning and to create the learning environment by doing, experiencing and having fun. Teachers have the primary duty of learning the techniques and implementing them. Carrying out activity development and implementation using different methods and techniques prior to their service periods will enable the teacher candidates to have positive opinions on the activity concept and help them in providing efficient learning (Girgin \& Şahin, 2019). For this reason, it is very important that the teacher candidates acquire experience on the different techniques, and their opinions on the techniques are also of significant importance.

\section{Purpose of the Research}

The aim of the study was to examine the effects on Primary School Teacher Candidates of developing and implementing jigsaw technique activities enriched with educational games in Science and Technology Teaching lessons. The research question for this purpose was determined as "What is the effect of developing and implementing Jigsaw technique activities enriched with educational games in the Science and Technology Teaching lessons on Primary School Teacher Candidates?" For this purpose, the following questions were sought.

\section{Research Questions:}

1. What is the effect of developing and implementing activities for the Jigsaw technique enriched with educational games in the Science and Technology Teaching lessons on the communication skills of Primary School Teacher Candidates?

2. What are the opinions of Primary School Teacher Candidates about developing and implementing activities for the Jigsaw technique enriched with educational games in the Science and Technology Teaching lessons?

It is thought that this research will contribute to increase the quality of the primary school teacher undergraduate program and to further the studies in this field.

\section{Method}

A mixed method pattern making use of both qualitative and quantitative research methods was used in the present study since the aim was to determine the 


\section{Acta Educationis Generalis \\ Volume 12, 2022, Issue 1}

impacts of "developing and implementing activities for the Jigsaw technique enriched with educational games" on the communication skills of classroom teacher candidates, as well as on their opinions related to the method. A mixed method study is defined as a study during which data are acquired and analyzed via both qualitative and quantitative approaches during a single study or a research program (Creswell, 2013; Johnson \& Onwuegbuzie, 2004). An explanatory mixed pattern was used from among the mixed method research types. Quantitative and qualitative data are actualized in two stages sequentially in the explanatory pattern. First, the quantitative data with priority in responding to the study questions are collected and analyzed. During the second stage, qualitative data are collected and analyzed in order to complete the data set (Creswell, 2013).

A single group pre-test post-test weak experimental pattern was used during the quantitative research stage of the study. Weak experimental patterns include studies with a single study group with no random selection (Büyüköztürk, Çakmak, Akgün, Karadeniz, \& Demirel, 2008). Lessons in the study group were carried out during the 2018-2019 academic year using the Jigsaw technique enriched with educational games (JTEEG) in Science and Technology II lessons. A case study pattern from among the study types was used during the qualitative research stage of the study. In the case study, the aim of the researcher is to focus on a single fact or event, and to describe and explain the relationship of important factors related to that event (Merriam, 2013).

The design of the study can be seen in Table 1 .

Table 1

Design of the study

\begin{tabular}{llll}
\hline & $\underline{\text { Pretest }}$ & $\underline{\text { Curriculum }}$ & $\underline{\text { Posttest }}$ \\
$\begin{array}{ll}\text { Research } \\
\text { Group }\end{array}$ & CSS & JTEEG & CSS \\
\hline
\end{tabular}

CSS: Communication Skills Scale

JTEEG: Jigsaw Technique Enriched With Educational Games

OFJTEEG: Opinion Form Jigsaw Technique Enriched With Educational Games

\subsection{Participants}

The purposeful sampling method was preferred in determining the participant group of the study (Miles \& Huberman, 1994). The reason why the purposeful sampling method was preferred is that it is aimed to determine the effects of developing Jigsaw technique activities enriched with educational games and applications of Primary School Teacher Candidates taking a Science and Technology Teaching course on their views on communication skills and methods. Patton (2001) emphasized that in the criterion sampling method, the 


\section{Acta Educationis Generalis \\ Volume 12, 2022, Issue 1}

participants of the study were determined according to a set of predetermined criteria. In the selection of the teacher candidates to participate in this study, it was determined as the basic criterion that the candidates were Classroom Teaching 3rd grade students who took the Science courses, Science and Technology Laboratory Applications and Science and Technology I courses. Therefore, the participant group of this study, in which the criterion sampling based on purposeful sampling is used, consists of 48 teacher candidates $(\mathrm{N}=12$ male and $\mathrm{N}=36$ female) who took the Science and Technology Teaching II lessons at Istanbul University, Faculty of Education, Primary Education Department Classroom Teaching Program in Turkey during the 2018-2019 academic year. The opinions of the teacher candidates were taken on a voluntary basis.

Incomplete scales were excluded from the sample and the data of the 48 preservice teachers were analyzed. Teacher candidates are between the ages of 2022. The lessons in the research group were carried out with JTEEG.

\subsection{Data collection instrument}

\subsubsection{Communication skills scale (CSS)}

The 5-point Likert type "Communication Skills Scale" developed by Korkut Owen and Bugay (2014) was used during the study for determining the communication skill levels of the teacher candidates. The scale is comprised of 25 items and has four factors. These four factors were named as: "Communication Principles and Basic Skills", "Personal Expression", "Active Listening and Nonverbal Communication" and "Willingness to Communicate". The scale has a Cronbach Alpha reliability coefficient of .88. High scale scores indicate increased communication skills. The lowest scale has minimum and maximum total scores of 25 and 125 respectively. The Cronbach Alpha reliability coefficient for the communication skills scale used in the present study was determined as .928 .

\subsubsection{Opinion form jigsaw technique enriched with educational games} (OFJTEEG)

In the study, the Opinion Form consisting of 13 open-ended questions was used in order to determine the opinions of the teacher candidates about the applications realized with the jigsaw technique enriched with educational games. While preparing the Opinion Form, attention was paid to making the questions easy and understandable, avoid guiding questions, not asking multi-dimensional questions, and organizing the questions within a certain logic (Yıldırım \& Şimşek, 2011). The Opinion Form questions were prepared by making use of (Hazar \& Altun, 2018; Seyhan \& Şimşek, 2019; Sömen \& Akcanca, 2018; Önen, Demir, \& Şahin, 2012) studies. The prepared questions were arranged after taking the opinions of two academics expert in their fields as well as two science teachers after which they were ready for the pilot study. The pilot study 


\section{Acta Educationis Generalis \\ Volume 12, 2022, Issue 1}

aims to determine the understandability and appropriateness of the questions and make revisions to develop a more reliable measurement tool (Glesne, 2012). For this purpose, 10 students were included in the pilot study. Based on the responses of the students, it was controlled whether the questions met the clarity requirements and whether they could provide the required data or not, after which necessary revisions were made, thus, finalizing the Opinion Form.

\subsection{Implementation process of the jigsaw technique enriched with educational games}

The study was carried out within the scope of the Science and Technology Learning II lessons during the spring semester of the 2018-2019 academic year. Teaching the subjects to the teacher candidates in accordance with the JTEEG for 3 lessons per week ( 3 lessons per week $=40$ minutes) and lasted 8 weeks. The time used for implementing the assessment tests was not included in the application process of the lessons. One week before the subjects were taught, a CSS test was given as a pretest. In addition, CSS and OFJTEEG were given as post-tests one week after teaching the subject.

Information on the jigsaw technique, educational games, educational game development, learning subjects, rules of the process, roles of the group members and evaluation strategies was provided before teaching the process to the groups. Eight heterogeneous groups of six people each were formed taking into consideration the weighted grade point averages of the teacher candidates and their genders. Each group was asked to select a name in order to encourage group spirit. The subjects under the "Properties of Matter" unit included in the 4th Grade Curriculum were classified into six sub-headings, after which each member of the group was asked to select a subject. Afterwards, teacher candidates who selected the same sub-heading were gathered in another group, thus, forming six expert groups. The subjects of the expert groups were properties of matter (Expert-1), measurable properties of matter (Expert-2), states of matter (Expert-3), transformation of matter by heat (Expert-4), pure matter and mixture (Expert-5) and mixture separation methods (Expert-6). The groups were then asked to prepare worksheets on their respective subjects in addition to developing an educational game for the assessment of subject related concepts. At this stage, the teacher candidates were asked to prepare their own worksheets in order to improve their research and communication skills since they are all university students. The students made use of books and online material during the specialization period for preparing the worksheets related to their subjects of specialization. At this stage, two academics provided feedback on the prepared worksheets, thus, guiding the students. Afterwards, the prepared worksheets and the developed educational games were presented to the academics for approval. Following the approval of the academics, the worksheets prepared by the expert groups were ready to use. Each expert student returned to their own respective groups at the end of the specialization period 


\section{Acta Educationis Generalis \\ Volume 12, 2022, Issue 1}

and conducted expert group teachings for a period of six weeks. Attention was given to ensure that there was a high level of interaction between the expert students and the other group members during the expert groups teaching period. Expert students did not only teach the subject but also used various methods such as brainstorming, question-answer and carried out an assessment on the level of learning of the group members by way of an educational game. Table 2 presents an in-depth explanation of the Jigsaw Technique Enriched with the Educational Games technique implementation process.

Table 2

Application process of jigsaw technique enriched with the educational games technique

\begin{tabular}{|c|c|}
\hline Week & Application process \\
\hline \multirow[t]{2}{*}{1} & Information on Jigsaw Technique and Sample Activity \\
\hline & Informing about the Educational Game and Conducting a sample activity \\
\hline \multirow[t]{4}{*}{2} & Creating Heterogeneous Groups \\
\hline & Giving names to groups \\
\hline & Determining the Topics \\
\hline & Establishing expert groups \\
\hline \multirow[t]{2}{*}{3} & Teaching the subject of "Properties of Matter" (Expert-1) \\
\hline & Playing the "Bingo" game in the evaluation phase \\
\hline \multirow[t]{2}{*}{4} & Teaching the subject of "Measurable Properties of Matter" (Expert-2) \\
\hline & Playing the game "Name-City" in the evaluation phase \\
\hline \multirow[t]{2}{*}{5} & Teaching the subject of "States of Matter" (Expert-3) \\
\hline & Playing the game "Don't Get Angry" in the evaluation phase \\
\hline \multirow[t]{2}{*}{6} & Teaching the subject of "Transformation of Matter by Heat" (Expert-4) \\
\hline & Playing the game "Taboo" in the evaluation phase \\
\hline \multirow[t]{2}{*}{7} & Teaching the subject of "Pure Matter and Mixture" (Expert-5) \\
\hline & Playing the "Tangram / Puzzle" game in the evaluation phase \\
\hline 8 & Teaching the subject of "Mixture Separation Methods" (Expert-6). \\
\hline & Playing the "Guess It" game in the evaluation phase \\
\hline
\end{tabular}

\subsection{Data analysis}

Detailed information on the analysis of the data obtained from the data collection tools used is presented under its own subtitle for each data collection tool.

1.4.1 Analysis of data obtained from the communication skills scale (CSS) In the quantitative data analysis, firstly Shapiro-Wilk results of pre-test and posttest data from the Communication Skills Scale (CSS) were examined to determine the normality of the distribution. As a result of the mentioned statistical analyses, it was found that the data were normally distributed. 


\section{Acta Educationis Generalis \\ Volume 12, 2022, Issue 1}

Therefore, parametric statistical analysis techniques were used because the data showed a normal distribution and the number of individuals in the sample was less than 50 (Büyüköztürk, 2019). The dependent group t-test was used to determine whether there was a statistically significant difference between pre and post tests related to the communication skills scale (CSS). A significance level of .05 was set in the interpretation of the data (Creswell, 2012). In order to interpret statistical significance, the effect size was employed in the research. Effect size ( $\eta 2)$ indicates how much the independent variable or factor explains the total variance in the dependent variable. Effect size ( $\eta 2)$ : It ranges from 0.00 to 1.00 , and $(\eta 2)$ values of $.01, .06$ and .14 are defined as small, medium, and large effect sizes in the same order. The Eta-squared statistic was used to calculate the effect size of the Dependent Samples $\mathrm{t}$-Test $(\mathrm{n}=$ number of samples) and the calculation was made with the formula $\eta 2=\mathrm{t} 2 / \mathrm{t} 2+(\mathrm{n}-1)$ (Büyüköztürk, 2019).

\subsubsection{Analysis of the data obtained from the opinion form jigsaw technique} enriched with educational games (OFJTEEG)

In the qualitative data analysis, an Opinion Form containing 13 open-ended questions was analyzed using content analysis and descriptive analysis methods during the study (Yıldırım \& Şimşek, 2011). The responses to the Opinion Form questions were written down in a computer environment during the first stage of the analysis, thus, preparing the data for analysis. Afterwards, all raw data were read, examined and classified, followed by the coding procedure (Rossman \& Rallis, 2003). The codes related with the same headings or subjects were grouped to form categories. Finally, similar categories were grouped under common themes. The names of the students were hidden during the analysis and codes such as $\mathrm{S} 1, \mathrm{~S} 2, \ldots, \mathrm{S} 41$ were used instead.

\subsection{Validity and reliability analysis}

Both quantitative and qualitative measurement tools were used in the study in accordance with the nature of the mixed method. For a study to be acceptable, it must have valid and reliable measurement tools. The reliability of the communication skills scale, which was used as a quantitative measurement tool in the study, was provided by Cronbach alpha analysis. Expert opinions were obtained from 2 faculty members and 2 science teachers in order to ensure the validity of the communication skills scale. In order to ensure the reliability of Opinion Form Jigsaw Technique Enriched with Educational Games, coding was done by 2 faculty members and 1 Science teacher who are experts in their field. In order to calculate the coding reliability, the Miles and Huberman's (1994) formula "reliability $=$ (number of consensus) / (total agreement + number of disagreement)" was used. Coding reliability was calculated as 0.92 . Since this value is above 0.70 , coding is considered reliable (Miles \& Huberman, 1994). In order to ensure the content validity of the form, 2 faculty members who are 


\section{Acta Educationis Generalis \\ Volume 12, 2022, Issue 1}

experts in their fields and 1 Science teacher examined the form, and the necessary corrections were made.

\section{Findings}

\subsection{Findings from the communication skills scale (CSS)}

The Communication Skills Scale (CSS) was applied to Primary School Teacher Candidates before and after teaching the subject in order to find an answer to the first research question of: "What is the effect of developing and applying activities for JTEEG on the communication skills of Primary School Teacher Candidates?"

Since the sample size in the study was smaller than 50, it was determined by the Shapiro-Wilks test whether the obtained data showed a normal distribution. As seen in Table 3, it was determined that each data set showed a normal distribution ( $p>0.05)$. For this reason, it was decided to use parametric statistical methods in the analysis of the data obtained from the Communication Skills test.

Table 3

Communication skills scale (CSS) Shapiro-Wilks test findings

\begin{tabular}{llccc}
\hline Scale & & Statistics & $\underline{d f}$ & $\underline{p}$ \\
CSS & Pretest & 0.968 & 48 & 0.208 \\
& Posttest & 0.953 & 48 & 0.054 \\
\hline
\end{tabular}

The Dependent group t-test was used to determine whether there was a significant difference between the Communication Skills Scale (CSS) mean scores of the Primary School Teacher Candidates before and after the JTEEG application. The findings presented in Table 4 show that there is a significant difference between Teacher Candidates' (CSS) average scores before and after the application $[\mathrm{t}(47)=2.09, \mathrm{p}<0.05, \eta 2=0.085]$. This difference is in favor of the posttest averages. Considering the effect sizes, the applied activities increase the communication skill levels of teacher candidates, it has been concluded that it has a broad impact level above the medium level. Therefore, it can be said that JTEEG applications positively contribute to the Communication skills of teacher candidates.

Table 4

Communication skills scale (CSS) pre-test - post-test dependent group t-test findings

\begin{tabular}{lllllllll}
\hline Scale & & $\underline{N}$ & $\underline{X}$ & $\underline{S S}$ & $\underline{S d}$ & $\underline{t}$ & $\underline{P}$ & $\underline{\eta 2}$ \\
& Pretest & 48 & 4.17 & .37 & & & & \\
& Posttest & 48 & 4.35 & .47 & 47 & 2.09 & .042 & .085 \\
\hline
\end{tabular}




\section{Acta Educationis Generalis \\ Volume 12, 2022, Issue 1}

\subsection{Findings on the opinion form jigsaw technique enriched with educational games (OFJTEEG)}

The Opinion Form Jigsaw Technique Enriched with Educational Games (OFJTEEG) was applied to the Primary School Teacher Candidates after teaching the subject in order to find an answer to the second research question of: "What are the opinions of Primary School Teacher Candidates on developing and implementing activities for the JTEEG?" Content analysis and descriptive analysis were performed on the responses of the teacher candidates to the questions in the Opinion Form in order to determine their opinions related to the technique.

Based on the content analysis findings of the study; four main themes were obtained: "Positive Opinions", "Negative Opinions", "Preferring the Technique" and "Technique-related changes suggestions". A table was prepared for each theme. The tables included findings on the frequency values of the codes. The findings were supported by direct citations.

\subsubsection{Theme 1: "Positive Opinions"}

The "Positive Opinions" theme was formed by taking into consideration the responses to the five Open-Ended question in the Opinion Form. Table 5 presents the distribution of the responses to the questions below directed at the students within the scope of Theme 1:

Question 1: What are your positive opinions on developing and implementing activities for the JTEEG when evaluated from the perspective of the teacher?

Question 2: What are your positive opinions on developing and implementing activities for the JTEEG when evaluated from the perspective of the student?

Question 3: What are your positive opinions on developing and implementing activities for the JTEEG when evaluated with regard to learning?

Question 4: What are your positive opinions on developing and implementing activities for the JTEEG when evaluated with regard to the teaching environment?

Question 5: What are your positive opinions on developing activities for the JTEEG when evaluated with regard to activity development process?

\section{Table 5}

Findings of primary school teacher candidates on the theme of "Positive Opinions"

\begin{tabular}{llc}
\hline Positive opinions about technique from the teacher perspective & $f$ \\
\hline $\begin{array}{l}\text { Enjoying the lesson with the educational game supported jigsaw } \\
\text { technique }\end{array}$ & 23 \\
2 & More communication with the students & 14 \\
3 & Being able to teach with a smaller group of students & 12 \\
4 & Providing experience for the teaching profession & 10 \\
\hline
\end{tabular}




\section{Acta Educationis Generalis \\ Volume 12, 2022, Issue 1}

5 Students can increase their motivation to the lesson $\quad 7$

6 Ability to learn a lot of new information by discussing in expert groups 5

Positive opinions about the technique from the student's perspective $f$

1 Enjoying the lesson with the educational game supported jigsaw 30 technique

2 Being always active in lessons $\quad 24$

4 Increased interest in the lesson $\quad 10$

5 Providing the opportunity to communicate with other students 7

6 Increasing self-confidence 5

Positive opinions about the technique with regard to learning $f$

$\begin{array}{lll}\text { P Providing permanence in learning } & 21\end{array}$

2 Providing better quality learning with creative activities 18

3 Providing the opportunity to learn while having fun with the educational 16 game supported application

4 Providing the opportunity to learn by doing and living 12

5 Learning can take place quickly 9

6 Ensuring the consolidation of the subject with the application supported 4 by educational games

Positive opinions about the technique with regard to the teaching $f$ environment

1 Allowing all students to communicate with each other 20

2 Allowing group work $\quad 12$

3 Provides many opportunities to learn new games 9

4 Providing a refined competition environment 7

Positive opinions about the technique with regard to activity development $f$ process

$1 \quad$ Enjoyable event development process $\quad 12$

$\begin{array}{ll}2 \text { Developing social skills } & 10\end{array}$

3 Ensuring academic development of the activity development process 8

4 Providing collaboration opportunity $\quad 7$

5 Providing an opportunity to increase creativity in the event development 6 process

6 Allowing the development of different ideas in the event development 5 process

In Table 5, it is seen that the teacher candidates have various positive opinions about developing and implementing activities related to JTEEG.

It was observed when the "Positive opinions about technique from the teacher perspective" were examined that the majority of the teacher candidates stated that JTEEG can be effective in ensuring that the lesson is enjoyable $(f=23)$. In addition, the participants also put forth positive opinions on JTEEG, such that it encourages more communication with the students $(f=14)$, classes have groups of fewer students $(f=12)$, provides experience on the teaching profession $(f=10)$, increases the motivation of the students towards the lesson $(\mathrm{f}=7)$ and enables the acquisition of new information through expert group discussions $(f=5)$. From the findings obtained, it can be said that teacher candidates enjoy teaching lessons in 


\section{Acta Educationis Generalis \\ Volume 12, 2022, Issue 1}

collaborative groups with educational games, they think of them as motivational environments and they think that they will experience the teaching profession by applying the jigsaw technique. The expressions of some of the teacher candidates on this issue are presented below:

T24: Educational games eliminated boredom. Using games for assessment rather than traditional methods made the class more interesting and joyful.

T10: It is positive that teachers interact more with each group member since the number of individuals in the groups is small. The students can express themselves more comfortably, thus, increasing participation.

T7: When we took on the role of the teacher for teaching this lesson, we had the opportunity to experience how we can teach this knowledge in a way that is in accordance with the level of the students.

It was observed when the "Positive opinions about the technique from the student's perspective" were examined that the majority of the teacher candidates indicated that lessons are much more joyful with JTEEG. Moreover, the participants also stated various positive opinions with regard to the actualized implementations such as being continuously active in the classroom ( $\mathrm{f}=24)$, increased interest towards the lesson $(\mathrm{f}=10)$, establishing communication with the other students $(f=7)$ and increasing self-confidence $(f=5)$. When evaluated from the obtained findings in terms of students, it can be said that teacher candidates are of the opinion that they enjoy teaching lessons in cooperative groups with educational games, increase their communication skills in the process, and increase their self-confidence as they actively participate in the process by applying the jigsaw technique.

The expressions of some teacher candidates have been presented below:

T3: The lesson was fun as a student because active learning and playing different educational games made it very entertaining.

T46: .I am of the opinion that it helps to improve communication since we get to work with peer groups a lot.

T44: It is a very effective method for students to learn both concepts and social relations. Learning through interacting with each other also improves the selfconfidence of students.

T12: This method also strengthens the communication of the students with their other friends. I had the chance to communicate with people in the classroom with whom I had not spoken before.

It was observed when "Positive opinions about the technique with regard to learning" were examined that the majority of the teacher candidates stated that JTEEG ensures permanence in learning $(\mathrm{f}=21)$. In addition, the participants also stated the following positive opinions on the implementations; ensuring a higher quality learning through creative activities ( $\mathrm{f}=18$ ), providing the opportunity to learn while having fun $(\mathrm{f}=16)$, providing the opportunity to learn by doing and experiencing ( $\mathrm{f}=12)$, ensuring faster learning $(\mathrm{f}=9)$ and reinforcing the subject further $(\mathrm{f}=4)$. From the findings obtained, it can be said that teacher candidates 


\section{Acta Educationis Generalis \\ Volume 12, 2022, Issue 1}

for learning are of the opinion that permanent learning is ensured while teaching in cooperative groups with educational games and learning in a fun and faster way.

The statements of some teacher candidates on this issue are presented below:

T10: It is a very nice method since it encourages creativity and requires active participation from each group member. Teaching the lesson through educational games makes it even more fun and ensures greater permanence in learning.

T17: Learning is more effective and fast since the activities and materials used during the lessons are easily accessible.

T4: Supporting the subject with educational games in an entertaining manner helped us to learn the rules of the game and further reinforce the subject.

T21: I believe it was a very permanent form of learning since all students learned by experience throughout the lesson.

T29: I believe that the students learned better since they were more active, and many games and activities were used throughout the lesson.

It was observed, when "Positive opinions about the technique with regard to the teaching environment" were examined that the majority of the teacher candidates stated that JTEEG enables all students to communicate with each other $(f=20)$. Moreover, the participants also put forth the following positive opinions on the implementations; encouraging group work $(\mathrm{f}=12)$, providing the opportunity to learn many new games ( $\mathrm{f}=9$ ) and establishing a refined environment for competition $(\mathrm{f}=7)$. From the findings obtained, it can be said that teacher candidates think that educational games and lessons taught in collaborative groups take place in environments that allow group work and communication, as well as provide opportunities for learning new games.

The statements of some teacher candidates on this issue are presented below:

T9...I wish to use the "Bingo" game that I used while teaching with my own students in the future. I had the chance to learn many new games that I can use in the future since the method is supported by games. The refined competition in the environment enabled us to follow the lesson enthusiastically with both our group and with other groups.

T16: The knowledge I acquired was permanent since I learned it through fun games, and I also have many ideas for games that I can use in the future.

T38: The teaching environment is much better than a regular classroom environment because there is one-to-one interaction with the students. Students can participate actively in all activities since the number of individuals in each group is small.

It was observed when the "Positive opinions about the technique with regard to activity development process" were examined that the majority of the teacher candidates stated that the activity development process for JTEEG is enjoyable $(\mathrm{f}=11)$. In addition, the participants also stated various positive opinions on the activity development process such as that it enables the development of social skills $(\mathrm{f}=10)$, enables academic development $(\mathrm{f}=8)$, provides opportunity for 


\section{Acta Educationis Generalis \\ Volume 12, 2022, Issue 1}

cooperation ( $\mathrm{f}=7$ ), enables the improvement of creativity $(\mathrm{f}=6)$ and the development of new ideas $(\mathrm{f}=6)$. From the findings obtained, it can be said that teacher candidates think that their social skills, creativity by developing new games, and their academic success by working together increase in lessons taught in collaborative groups by developing educational games.

The opinions of some teacher candidates on this issue are presented below:

T2: Our creativity increased significantly when developing the activities.

T9: Prior to the lesson, we designed the experiments and activities together with our friends to be presented to the group. Hearing new ideas from my friends during this period, and debating with them, improved our learning significantly. T42: I enjoyed it a lot since I worked with my friends during the activity development process.

T20: Skills of socialization and cooperation increase since this is group work.

\subsubsection{Theme 2: "Negative Opinions"}

The "Negative Opinions" theme was formed by taking into consideration the responses to the five open ended questions in the opinion form. Table 5 presents the distribution of the responses to the questions below directed at the students within the scope of Theme 2:

Question 1: What are your negative opinions on developing and implementing activities for the JTEEG when evaluated from the perspective of the teacher?

Question 2: What are your negative opinions on developing and implementing activities for the JTEEG when evaluated from the perspective of the student?

Question 3: What are your negative opinions on developing and implementing activities for the JTEEG when evaluated with regard to learning?

Question 4: What are your negative opinions on developing and implementing activities for the JTEEG when evaluated with regard to the teaching environment?

Question 5: What are your negative opinions on developing activities for the JTEEG when evaluated with regard to activity development process?

Table 6

Findings of primary school teacher candidates on the theme of "Negative Opinions"

Negative opinions about technique from the teacher perspective

1 Difficulty in classroom control in the implementation of activities

$f$

2 Application requires preparation 9

Negative opinions about the technique from the student's perspective

1 Difficulty working together for students with different levels of sense of 1 responsibility

Negative opinions about the technique with regard to learning

1 It is boring to be constantly active

Negative opinions about the technique with regard to the teaching $f$ 
environment

\begin{tabular}{lll}
\hline & Difficulty practicing in crowded groups & 6
\end{tabular}

2 Difficulty applying in the classroom 5

3 Time management difficulties related to the event 4

Negative opinions about the technique with regard to activity development $f$ process

$\begin{array}{llll}1 & \text { Difficulty in developing the activity in accordance with the student level } & 8\end{array}$

2 Difficulty working with students of different opinions while developing 7 activities

In Table 6, teacher candidates stated that they have some negative opinions with regard to JTEEG in addition to the positive opinions. While some teacher candidates indicated that they do not have any negative opinions on jigsaw applications enriched with educational games.

It was observed when the "Negative opinions about technique from the teacher perspective" were examined that it may lead to difficulties in classroom control $(\mathrm{f}=9)$ and that it may require preparation $(\mathrm{f}=6)$. When the findings are evaluated from the point of view of the teacher, it can be said that the teacher candidates have difficulty controlling the class the most in the lessons taught in cooperative groups with educational games. The expressions of some teacher candidates on this issue are given below:

T24: It may be difficult to control the class with young age groups.

T2: It requires extra time before the lessons since we would need to make preparations.

It was observed when the "Negative opinions about the technique from the student's perspective" were examined that one participant indicated that students with different levels of sense of responsibility may have difficulties in working together $(\mathrm{f}=1)$. When the obtained findings are evaluated from the point of view of the student, it can be said that a large proportion of teacher candidates do not have a negative opinion about the lessons taught in cooperative groups with educational games, while the negative opinion teachers have difficulty in working with individuals with different knowledge levels and character traits. The expression of the teacher candidate on this issue is provided below:

T20: Even though working with the group has positive aspects, there may be some people who do not have a group culture. There are also people who do not produce any ideas on what should be done or those who do not take on any duties. That is why the other group members have difficulties.

It was observed when the "Negative opinions about the technique with regard to learning" were examined that the participants stated that it is boring to continuously perform new activities $(\mathrm{f}=1)$. From the findings obtained, it can be said that the teacher candidates think that it can be boring to do new activities continuously while learning takes place in the lessons taught in collaborative groups with educational games. The expressions of some teacher candidates on this issue are presented below: 


\section{Acta Educationis Generalis \\ Volume 12, 2022, Issue 1}

T47: It was nice to learn the subject through activities, however, after a while, performing activities all the time ended up becoming boring.

It was observed when the "Negative opinions about the technique with regard to the teaching environment" were examined that the participants stated that it is difficult to implement the developed activities in crowded groups $(\mathrm{f}=6)$ and in a classroom environment $(\mathrm{f}=5)$, and that activity related time management is difficult ( $\mathrm{f}=4$ ). From the findings obtained, it can be said that teacher candidates had difficulties due to crowded classes and time limitations in lessons taught in collaborative groups with educational games.

The expressions of some teachers on this issue are presented below:

T15: It is difficult in very crowded groups. Learning is certainly hampered if there is chaos in the environment. Attention is required during the experiments and activities.

T43: ......takes too long. The teacher may not end up teaching the subject in full in the allotted time frame. The students may get bored.

T9: The fact that the environment is a regular classroom environment may have resulted in noise.

It was observed when the "Negative opinions about the technique with regard to activity development process" were examined that the participants stated that it may be difficult to develop the activity in accordance with the student level $(\mathrm{f}=8)$, and that it may be difficult for students with different opinions to work together $(\mathrm{f}=7)$. From the findings obtained, it can be said that teacher candidates have difficulty in developing educational games and working with pre-service teachers who have different mentalities and knowledge levels in lessons taught in cooperative groups.

The statements of some teacher on this issue are provided below:

T37: We had a difficult time when trying to prepare an activity that suited the class level.

T28: We had a clash of ideas while developing the activity. We tried to select ideas from among them.

\subsubsection{Theme 3: "Preferring the Technique"}

The theme of "Preferring the Technique" was formed based on the responses to the 2 open ended questions included in the opinion form. Table 7 presents the distribution of the responses to the following questions directed to the students for Theme 3:

Question 1: Would you prefer using JTEEG in your lessons when you become a teacher?

Question 2: In which lessons would you prefer to use JTEEG? 


\section{Acta Educationis Generalis \\ Volume 12, 2022, Issue 1}

\section{Table 7}

Findings of primary school teacher candidates on the theme of "Negative Opinions"

\begin{tabular}{lr}
\hline Preference to implement the technique & $f$ \\
$1 \quad$ Certainly prefer & 39 \\
$2 \quad$ Prefer to implement from time to time & 3 \\
$3 \quad$ Prefer to implement for acquisitions that require activities & 2 \\
$4 \quad$ Would not prefer & 4 \\
Lesson preference where the technique will be implemented & $f$ \\
$1 \quad$ Preferring to use in all lessons & 16 \\
$2 \quad$ Preferring to use in science and mathematics lessons & 13 \\
$3 \quad$ Preferring to use in science lessons & 9 \\
$4 \quad$ Preferring to use in science, social and mathematics lessons & 6 \\
\hline
\end{tabular}

It was observed when the "Preference to implement the technique" was examined that the participants stated opinions such as "certainly prefer" ( $\mathrm{f}=39)$, "prefer to implement from time to time" $(\mathrm{f}=3)$, "prefer to implement for acquisitions that require activities" ( $\mathrm{f}=2$ ) and "would not prefer" $\mathrm{f}=4$ ). From the findings obtained, it can be said that the majority of the teacher candidates preferred teaching the lessons in collaborative groups with educational games. The expressions of some teachers on this issue are presented below:

T16: I would want to use this technique when I become a teacher, to ensure that the students are more active, that they take on responsibility and because it makes the lessons more fun and permanent.

T26: I can say that this would be one of the techniques that I will implement when I become a teacher because I am of the opinion that it makes the lessons more fun while ensuring that the acquired knowledge is permanent.

T5: I do not prefer to use it in the future because it requires a lot of time.

It was observed when the "Lesson preference where the technique will be implemented" was examined that the participants stated opinions such as "Preferring to use in all lessons" ( $\mathrm{f}=16)$, "Preferring to use in science and mathematics" ( $\mathrm{f}=13$ ), "Preferring to use in science lesson" ( $\mathrm{f}=9$ ), and "Preferring to use in science, social and mathematics lessons" $(\mathrm{f}=6)$. From the findings obtained, it can be said that the majority of the teacher candidates think of applying it in all lessons teaching lessons in collaborative groups with educational games, and some of them prefer to apply especially in abstract lessons such as science and mathematics. The expressions of some teachers on this issue are presented below:

T2: It may be useful to use it in lessons containing abstract subjects such as science and mathematics.

T33: I can use this technique in every lesson because it is a technique that can be applied in every lesson. 


\section{Acta Educationis Generalis \\ Volume 12, 2022, Issue 1}

\subsubsection{Theme 4: "Technique-related Changes Suggestions"}

The theme of "Technique-related Changes Suggestions" was formed based on the responses to the 1 open ended question included in the opinion form. Table 8 presents the distribution of the responses to the following question directed to the students for Theme 4:

Question 1: If you wanted to replace JTEEG, what would your suggestions be?

\section{Table 8}

Findings of primary school teacher candidates on the theme of "Techniquerelated changes suggestions"

\begin{tabular}{|c|c|}
\hline Technique-related changes suggestions & $f$ \\
\hline 1 Not wanting to change & 37 \\
\hline Increasing the number of games & 5 \\
\hline Add different events & 4 \\
\hline 5 Application in laboratory environment & 2 \\
\hline
\end{tabular}

It was observed when the "Technique-related changes suggestions" was examined that the participants stated that they do not want to make changes $(\mathrm{f}=37)$, they want to increase the number of games $(\mathrm{f}=5)$, they want to add different activities $(\mathrm{f}=4)$, and they suggest working in the laboratory environment ( $\mathrm{f}=2$ ). From the findings obtained, it can be said that the majority of the teacher candidates did not prefer to change anything related to the teaching of lessons in cooperative groups with educational games. This finding can be thought of as indicative that most of the pre-service teachers liked the technique. The expressions of some teachers on this issue are presented below; T21: I wouldn't want to change anything.

T46: I think it might be possible to increase the number of games.

\section{Discussion and conclusions}

The aim of the present study was to examine the impacts of developing and implementing activities for JTEEG on Primary School Teacher Candidates. For this purpose, the Science and Technology Teaching II lessons included in the Primary Education Department Classroom Teaching Program at the Istanbul University Faculty of Education during the 2018-2019 academic year was carried out by developing and implementing activities for JTEEG.

It was determined when the data acquired from the Communication Skills Scale (CSS) applied for evaluating the impacts of developing and implementing activities for JTEEG on the communication skill levels of classroom teacher candidates were examined that there was a statistically significant difference between the communication skill levels of the teacher candidates before and after the implementation. The acquired findings point out that the communication skills of teacher candidates have developed significantly with 


\section{Acta Educationis Generalis \\ Volume 12, 2022, Issue 1}

the implemented technique. Throughout the implementation period, the teacher candidates prepared worksheets together with the group members on the subjects of expertise making use of books and online material, developed an educational game for the assessment of the concepts related with the subject at hand and communicated actively with the group members. It can be thought that as a result of the active participation of the teacher candidates in the lesson, their teacher-student interaction, and their fulfillment of their assigned tasks by taking responsibility, and their communication skills have been developed. It was determined, as a result of the study, that the use of the jigsaw technique, which is one of the cooperative learning methods, together with educational games provide opportunities to the classroom teacher candidates for improving their communication skills, and that the communication skills of teacher candidates improved as a result. Even though no studies could be found in the literature examining the impact of developing and implementing activities for JTEEG on the communication skills at the teacher candidate level, Halimah and Sukmayadi (2019) put forth that implementing the jigsaw technique is successful for improving the verbal communication skills of teacher candidates. Prastyo (2017) found in Indonesia that the cooperative learning method significantly increased the communication competencies of teacher candidates in her study, in which she investigated the effect on the communication competencies of pre-service teachers. There are studies investigating the effect of cooperative learning on communication skills at different learning levels. Towns and Grant (1997) found that cooperative learning improves the interaction between students and interpersonal communication skills as a result of the study in which she applied the cooperative learning method in the teaching of Thermodynamics course at the graduate level. In a different study, Çatalkaya (2019) conducted a study on the impacts of the Jigsaw I technique implemented for teaching "the Household Wastes, Recycling and Chemical Industry" subjects of the Science lesson for seventh grade secondary school students. It has been emphasized as a result of the study that the jigsaw technique has improved the communication skills. Studies conducted in the literature show that the cooperative learning method supports communication and interaction (Sar1goz, 2017). Moreover, it is emphasized, in accordance with the results of studies conducted using the jigsaw technique, that the jigsaw technique contributes to improving various skills of students such as teamwork skills, critical thinking skills, laboratory material recognition and usage skills, as well as communication skills (Artut \& Tarim,

2007; Perkins \& Saris, 2001; Kumar, Kalasuramath, Patil et al., 2017; Souvignier \& Kronenberger, 2007).

Based on the analysis of the data acquired from OFJTEEG applied for the assessment of the opinions of classroom teacher candidates on developing and implementing activities for JTEEG, the opinions of the classroom teacher candidates were classified under four main headings as; "Positive Opinions", 


\section{Acta Educationis Generalis \\ Volume 12, 2022, Issue 1}

"Negative Opinions", "Preferring the Technique" and "Technique-related
changes suggestions". The "Positive Opinions" theme includes the positive contributions according to the classroom teacher candidates of lessons taught with JTEEG, such as making the lessons more joyful, providing experience for the teaching profession, enabling academic development, ensuring learning permanence, enabling more interest in the lesson, improving communication skills, facilitating learning through having fun, encouraging the students to be more active in class, improving creativity, increasing self-confidence and enabling high quality learning through activities. It can be concluded based on the study results that the teacher candidates enjoyed developing educational games for the topic at hand as well as developing and implementing activities for the jigsaw technique. It can be thought that the pre-service teachers showed academic success on the subject area and gained experience in the teaching profession by helping each other to learn by using the jigsaw technique. Nhu (1999) investigated the behaviors of students working in a cooperative learning environment, students' thoughts about cooperative learning and their attitudes towards this learningteaching method in a study conducted with 27 students studying in the chemistry department of a university. As a result of the study, it was determined that the cooperative learning approach helps students learn, and they understand the subject better when working together in small groups. A different study stated that the cooperative learning method helped pre-service teachers to see themselves as teachers (Turaçoğlu, Alpat, \& Ellez 2013). In parallel with the results obtained from their study, Ilgaz, Çalıklar, Yıldız and Şimşek's (2018) studies of teacher candidates' views on Jigsaw and Let's Ask Together Let's Learn Together techniques reveal that teacher candidates' collaborative learning techniques increase their self-confidence, improve their communication skills, and affect their perspective on group work positively. It was determined that they used expressions as changed. This can be considered to be due to JTEEG that encouraged the students' active participation in the class, in addition to enabling the students to be included in all stages of learning while providing them the opportunity for learning the subject through games. Teaching with games is described as a recently renewed field that can be used for learning purposes (Charsky \& Ressler, 2011). In addition, it has been determined that the games offer environments that support cooperation, increase the level of motivation and self-confidence of the students, and make them interested in the subject (Bayırtepe \& Tüzün, 2007). The results of the study are in accordance with the results of previous studies conducted using educational games and the Jigsaw technique (Bayat, Kılıçarslan, \& Şentürk, 2014; Savaş \& Gülüm, 2014; Önen, Demir, \& Şahin, 2012; Doğan, Uçar, \& Şimşek, 2015; Yıldız, Şimşek, \& Ağdaş, 2017; Jansoon, Somsook, \& Coll, 2008; Amedu \& Gudi, 2017). Önen, Demir and Şahin (2012) carried out a study during which the opinions of science teacher candidates on games were acquired, and the developed games were 


\section{Acta Educationis Generalis}

Volume 12, 2022, Issue 1

evaluated, as a result of which, it was determined that teacher candidates have positive opinions on the use of games in teaching science; and it was also determined that the developed games were of high quality and educating. Jansoon, Somsook and Coll (2008) examined the impact of the jigsaw technique on attitude in teaching chemistry. The study was conducted with 244 first year undergraduate students at Thai University. The students indicated that they do not like the chemistry lessons prior to the implementation, whereas they indicated that they learned more and that their self-confidence levels increased after the implementation. Even though a limited number of studies have been determined in the cooperative learning methods integrated with educational games, Yıldız, Şimşek and Ağdaş (2017) have also obtained similar results to those of the present study. It was determined, as a result of the implementation, that the students subject to cooperative learning model enhanced with educational games have a higher motivation towards learning science, and that their social skill levels were higher at a statistically significant level.

Even though the majority of the classroom teacher candidates expressed positive opinions on the lessons taught via JTEEG under the "Negative Opinions" theme, a small number of teacher candidates put forth that the technique has adverse impacts, such as difficulties in classroom control, time management when implementing the activities, developing the activities in accordance with the student level and working together with students with different characteristics. It can be considered, based on the study results, that the teacher candidates may have experienced difficulties in classroom management and time management due to excessive noise and discussions between the students during group work, in addition to various other problems and difficulties partially resulting from students with different characteristics, placing the burden and responsibility on other members. Similar to the results obtained from the study, Edgerton and McKechnie (2002) found in their study that a large number of group members and having to spend too much time for group work outside of class negatively affected group work. In Salomon and Globerson's study (1989), the students who contributed to the group saw that some students got a good grade because the group was successful even though they did not contribute anything to the group, and they did not want to continue their group work. Seyhan and Şimşek (2019) conducted a study in which the implementation was made using the jigsaw technique which put forth that some of the students disturbed the other students instead of working with their own groups and that they got bored because the group work took very long. It is very important to create positive interdependence and harmony within the group. When intra-group disputes are not resolved, students can even move away from the task (Gibbs, 1995). For this reason, cooperative learning environments (individual responsibility, positive interdependence, face-to-face interaction, social skills and group process) should be arranged in accordance with the criteria (Johnson \& Johnson, 1989). In this study, teacher candidates had difficulties in developing activities. It can 


\section{Acta Educationis Generalis \\ Volume 12, 2022, Issue 1}

especially be stated that the reason why teacher candidates experience difficulties in developing activities in line with the student level is their lack of experience on this subject. Tuzcuoğlu, Güven and Efe (2006) conducted a study during which they reported that the game should be suited to the age of the child, the interests and needs of the child, as well as the development characteristics of the age group. This shows that the teacher candidates should take into consideration the age-class levels of the students when designing activities. Kapucu and Çağlak (2018) carried out a different study as a result of which they reported that the teacher candidates experienced difficulties in coming up with games during the implementation. This shows that the teacher candidates should take into consideration the age-class levels of the students when designing activities. Hence, we are of the opinion that teacher candidates should be given the opportunity to take part in many implementations in order to become competent in preparing games and activities in accordance with the classroom level.

The majority of the classroom teacher candidates stated with regard to the lessons taught via JTEEG under the "Preferring the Technique" theme that they would prefer using the technique in their lessons, since it makes the lessons more fun while also ensuring higher permanence in learning. There are also similar results in the literature. Şimsek, Örten, Topkaya and Y1llar (2014) reported in their studies that the teacher candidates stated that cooperative learning techniques increase academic success while also making significant contributions to them from a social and psychological perspective. Kurbaş and Girgin (2018) put forth in another study examining the importance of the educational games technique in teaching from the perspective of teachers, that the reasons why teachers prefer the technique are increasing classroom attendance, acquisition of behaviors and the reinforcement of the acquired behaviors, in addition to developing skills such as socialization, tolerance, assertion, communication and responsibility. Whereas a small number of teacher candidates stated that they would not prefer using the technique in their future lessons because its implementation time is very long. This is considered to be due to the inexperience of the teacher candidates both in the subject and the technique, due to their lack of previous experience in using the technique. The majority of the teacher candidates who preferred to use the technique indicated that they would like to use it in all lessons, while some stated that they would especially want to implement the technique in lessons such as Science and Mathematics that include abstract concepts. Science lessons are among the lessons that students struggle with since they include a great number of abstract concepts. Hence, implementations that will make these concepts more tangible are important for facilitating the teaching of these lessons. Similarly, Göktaş, Küçük and Topçu (2014) reported in their studies that educational games visualize the concepts, thus, making them more concrete. 


\section{Acta Educationis Generalis \\ Volume 12, 2022, Issue 1}

While the majority of the classroom teacher candidates stated that they are satisfied with the lessons carried out using JTEEG under the "Suggestions for technique related changes" theme, and that they do not want to make any changes, some have indicated that they want the number of games to be increased because they make the lessons fun. Un Aç1kgöz (2008) states that the games developed by teachers and students using their own creativity or adapted from daily life to the classroom will help the students to learn, and that including games in learning-teaching processes will make the lessons interesting, and students will be motivated. It can be said that with the educational games performed and applied in the study, teacher candidates' motivation for the lesson increased, and they liked the learning environment that offers the opportunity to learn by living by doing in cooperative groups.

In conclusion, it was observed, as a result of the present study on the impacts of developing JTEEG related activities and implementing them that the technique used in this study resulted in an increase in the communication skill levels of teacher candidates. Communication is among the concepts that we should focus on during the present century. It is important that teacher candidates who will be educating students in the future develop their skill levels in order to improve the communication skills of their students. As can be understood from the results of the present study, JTEEG is effective in developing the communication skills of classroom teacher candidates. Hence, it can be suggested in the light of the findings of this study that education environments should be arranged based on JTEEG.

There were several limitations to this study. This research relied on only Primary School Teacher Candidates' data and the study data were only collected in Turkey, and so, the study results are only regionally generalizable. It is suggested to implement the study on teacher candidates continuing their educations in different disciplines and regions. It can be stated, based on the statements of the teacher candidates, that they mostly have positive opinions on the implemented technique. Science lessons are among the lessons that students mostly approach with concern. The fact that they involve abstract concepts and that some of its subjects are perceived as difficult are among the reasons for this concern. Students get to take the science lessons for the first time in 3rd grade. It is very important that the classroom teachers who will teach the science lessons for the first time increase the interest in the class making sure that the students enjoy science. It is up to classroom teachers to make the science lessons popular, and to attract students' attention. In addition to knowing the subject area, the teacher should also be creative to attract students' attention to the lessons. A teacher should not only be creative in thinking, but should also be creative in matters of emotions, motivation, socialization, communication skills, collaboration, etc. (Novotná, Verbovanec, \& Török, 2013). One of the environments where both teachers and students can reveal their creativity and learn with fun is the Jigsaw Technique Activities Enriched with Educational 


\section{Acta Educationis Generalis \\ Volume 12, 2022, Issue 1}

Games applied in the study.It can be put forth, based on the findings of the study, that JTEEG is quite effective in making children like the science lessons and learn through enjoyment, since it enables them to be more active, creative, and take responsibility, while providing them with the opportunity to develop new games and activities, establish more communication with the other students, in addition to making abstract concepts more concrete. Hence, it is very important that the techniques that will be used for this purpose are first learned and implemented by teacher candidates. We are of the opinion that the hours should be increased for applied lessons on the technique. The implementation developed through the integration of educational games and the jigsaw technique from among cooperative learning methods has been limited to the "Properties of Matter" unit in the science lesson. It can be considered that implementing this technique on other subjects of the Science lessons will enable the students to find science more attractive and interesting, thereby making a significant contribution to science through facilitating rapid learning.

\section{References}

Abu Seileek, A. F. (2012). The effect of computer assisted cooperative learning methods and group size on the EFL learners' achievement in communication skills. Computers and Education, 58(1), 231-239.

Akinsola, M. K., \& Animasahun, I. A. (2007). The effect of simulation-games environment on students' achievement in and attitudes to mathematics in secondary schools. Turkish Online Journal of Educational Technology -TOJET, 6, 3.

Aksoy, G., \& Gürbüz, F. (2012). İşbirlikli iki farklı tekniğin öğrencilerin akademik başarıları üzerine etkisi. Elektronik Sosyal Bilimler Dergisi, 11(42), 67-78.

Amedu, O. I., \& Gudi, K. C. (2017). Attitude of students towards cooperative learning in some selected secondary schools in nasarawa state. Journal of Education and Practice, 8(10), 293.

Andic, B., Kadic, S., Grujicic, R., \& Malidzan, D. (2018). A Comparative analysis of the attitudes of primary school students and teachers regarding the use of games in teaching. IAFOR Journal of Education, 6, 2.

Artut, P. D., \& Tarim, K. (2007). The effectiveness of jigsaw II on prospective elementary school teachers. Asia-Pacific Journal of Teacher Education, 35(2), 129-141.

Aronson, E., Blaney, N., Stephan, C., Sikes, J., \& Snapp, M. (1978). The Jigsaw Classroom. Beverley Hills, CA: Sage

Atwood, R. K., \& Atwood, V. A. (1997). Effects of instruction on preservice elementary teachers' conceptions of the causes of night and day and the seasons. Journal of Science Teacher Education, 8(1), 1-13.

Bakker, M., Van den Heuvel-Panhuizen, M., \& Robitzsch, A. (2015). Effects of playing mathematics computer games on primary school students' multiplicative reasoning ability. Contemporary Educational Psychology, 40, 55-71.

Bayat, S., Kılıçarslan, H., \& Şentürk, Ş. (2014). Fen ve Teknoloji dersinde eğitsel oyunların yedinci sınıf öğrencilerinin akademik başarısına etkisinin incelenmesi. Abant İzet Baysal Üniversitesi Ë̆itim Fakültesi Dergisi, 14(2), 204-216.

Bayrakçeken, S., Doymuş, K., \& Doğan, A. (2015). İsbirlikli öğrenme modeli ve uygulanması. Ankara: Pegem Akademi. 


\section{Acta Educationis Generalis \\ Volume 12, 2022, Issue 1}

Bayırtepe, E., \& Tüzün, H. (2007). Oyun-tabanlı öğrenme ortamlarının öğrencilerin bilgisayar dersindeki başarıları ve öz-yeterlik algıları üzerine etkileri. Hacettepe Üniversitesi Eğitim Fakültesi Dergisi, 33, 41-54.

Berns, A., Isla-Montes, J. L., Palomo-Duarte, M., \& Dodero, J. M. (2016). Motivation, students' needs and learning outcomes: A hybrid game-based app for enhanced language learning. Springer Plus, 5(1), 1-23.

Büyüköztürk, Ş. (2019). Sosyal bilimler için veri analizi el kitabı (26. Baskı). Ankara: Pegem Yayınları.

Büyüköztürk, Ş., K1lıç Çakmak, E., Akgün, Ö. E., Karadeniz, Ş., \& Demirel, F. (2008). Bilimsel araştırma yöntemleri (14. Bask1). Ankara: Pegem Yayınları.

Charsky, D., \& Ressler, W. (2011). "Games are made for fun": Lessons on the effects of concept maps in the classroom use of computer games. Computers \& Education, 56, 604-615.

Cohen, E. G. (1986). Desining groupwork: Strategies for heterogeneoas classroom. New York: Colombia University Teacher College.

Cop, M. R., \& Kablan, Z. (2018). The analysis of studies on educational games in Turkey. Kocaeli University Journal of Education, 1(1), 52-71.

Çatalkaya, F. B. (2019). Jigsaw ı tekniğinin 7. sınıf ögrrencilerinin çevresel farkındalıklarına, iletişim becerilerine ve fen ögrenmeye yönelik motivasyonlarına etkisi (Master's thesis). Pamukkale Üniversitesi, Eğitim Bilimleri Enstitüsü, Denizli.

Creswell, J. W. (2012). Educational Research: Planning, Conducting, and Evaluating Quantitative and Qualitative Research (4th edition). Boston: Pearson.

Creswell, J. W. (2013). Research Design: Qualitative, Quantitative, and Mixed Approaches (4th edition). Thousand Oaks, CA: Sage.

Çepni, S. (Ed.). (2011). Fen ve teknoloji öğretimi. (9. Baskı). Ankara: Pegem.

Çepni, S., Küçük, M., \& Ayvacı, H. Ş. (2003). A study on implementation of the science program at the first grade of primary schools. Gazi Eğitim Fakültesi Dergisi, 23(3), 131-145.

Demirel, Ö. (2001). Eğitim sözlüğ̈̈. Ankara: Pegem A.Yayıncılık.

Demirel, Ö. (2002) Programdan değerlendirmeye ögretme sanatı. Ankara: Pegem.

De Vries, D. L., \& Edwards, K. J. (1974). Student teams and learning games: Their effects on cross-race and cross-sex interaction. Journal of Educational Psychology, 66(5), 741-749.

Doğan, A., Uçar, S., \& Şimşek, Ü. (2015). Jigsaw tekniğinin 6. sınıf fen ve teknoloji dersi "yer kabuğu nelerden oluşur?" ünitesinin öğretiminde öğrenci başarısına etkisi. Mustafa Kemal University Journal of Graduate School of Social Sciences, 32, 416-432.

Doymus, K. (2007). Effects of a cooperative learning strategy on teaching and learning phases of matter and one-component phase diagrams. Journal of Chemical Education, 84(11), 18571860.

Dönmez, İ., Tekçe, M., \& Kirmit, Ş. (2020). Using digital games in technology oriented stem education: the examination of the students' game designs. Journal of Education in Science Environment and Health, 6(2), 77-91.

Edgerton, E., \& Mckechnie, J. (2002). Students' view of group-based work and the issue of peer assessment. Psychology Teaching and Learning, 2, 76-81.

Gibbs, G. (1995). Learning in Teams: A Tutor Guide. Oxford: The Oxford Centre For Staff Development.

Girgin, D., \& Şahin, Ç. (2019). Sınıf öğretmenlerinin mesleki kimliklerine yönelik görüşleri. Mediterranean Journal of Educational Research, 13, 33-65.

Glesne, C. (2012). Nitel araştırmaya giriş. Ankara: Anı Yayıncılık.

Gonzalez-Gonzalez, C., \& Blanco-Izquierdo, F. (2012). Designing social videogames for educational uses. Computers \& Education, 58(1), 250-262.

Göktaş, Y., Küçük, S., \& Topçu, H. (2014). Sınıf öğretmeni adaylarının ilköğretim matematik öğretiminde eğitsel bilgisayar oyunlarının kullanımına yönelik görüşleri. Turkish Journal of Computer and Mathematics Education, 5(2), 119-136. 


\section{Acta Educationis Generalis \\ Volume 12, 2022, Issue 1}

Gündüz, M., Aktepe, V., Uzunoğlu, H., \& Gündüz, D. (2017). Okul öncesi dönemdeki çocuklara eğitsel oyunlar yoluyla kazandırılan değerler. Muğla Sitkı Koçman Üniversitesi Ĕ̆itim Fakültesi Dergisi, 4(1), 62-70.

Halimah, L., \& Sukmayadi, V. (2019). The role of "Jigsaw" method in enhancing Indonesian prospective teachers' pedagogical knowledge and communication skill. International Journal of Instruction, 12(2), 289-304.

Hazar, Z., \& Altun, M. (2018). Eğitsel oyunlara yönelik öğretmen görüşleri ve yeterliliklerinin incelenmesi. CBÜ Beden Eğitimi ve Spor Bilimleri Dergisi, 13(1), 52-72.

Hedeen, T. (2003). The reverse jigsaw: A process of cooperative learning anddiscussion. Teaching Sociology, 31(3), 325-332.

Henderson, T. L., \& Martin, K. (2002). Coperative learning as one approach to teaching family law. Family Law, 51, 351-360.

Higher Education Council [HEC]. (2007). Education faculty teacher training undergraduate programs. Retrieved from https://www.yok.gov.tr/Documents/Yayinlar/Yayinlarimiz/ egitim-fakultesi-ogretmen-yetistirme-lisans-programlari.pdf

Holliday, D. C. (2000). The development of Jigsaw IV in a secondary social studies classroom. Retrieved from ERIC database.

Johnson D. W., \& Johnson, R. T. (1991). Learning together and alone (3rd edition). Sydney: Allyn \& Bacon.

Johnson, D.W., \& Johnson, R. (1989). Cooperation and competition: Theory and research. Edina, MN: Interaction Book Co.

Johnson, D. W., \& Johnson, R. T. (2005). New developments in social interdependence theory. Psychological Monographs, 131(4), 285-358.

Jansoon, N., Somsook, E., \& Coll, R. K. (2008). Thai undergraduate chemistry practical learning experiences using the jigsaw IV method. Journal of Science and Mathematics Education in Southeast Asia, 31(2), 178-200.

Johnson, R. B., \& Onwuegbuzie, A. J. (2004). Mixed methods research: A research paradigm whose time has come. Educational Researcher, 33(7), 14-26.

Kapucu, M. S., \& Çağlak, S. (2017). Fen bilgisi öğretmen adaylarının eğitsel oyun tasarlama ve sürece ilişkin görüşler: bir durum çalışması. Adlyaman Üniversitesi Sosyal Bilimler Enstitüsü Dergisi, 10, 29.

Kaya, S., \& Elgün, A. (2015). Eğitsel oyunlar ile desteklenmiş fen öğretiminin ilkokul ögrencilerinin akademik başarısına etkisi. Kastamonu Eğitim Dergisi, 23(1), 329-342.

Kirriemuir, J., \& Mcfarlane, A. (2004). Literature review in games and learning. Futurelab Series.

Kırbaş, S., \& Girgin, G. K. (2018). The investıgatıon of teachers' opinions about educatıonal game techniques in education at primary schools. The Journal of Academic Social Science Studies International Journal of Social Science, 65, 521-538.

Kumar, C. V., Kalasuramath, S., Patil, S., Kumar, K. R., Taj, K. S., Jayasimha, V. L., Basavarajappa, K. G., Shashikala, P., Kukkamalla, A., \& Chacko, T. (2017). Effect of jigsaw co-operative learning method in improving cognitive skills among medical students. International Journal of Current Microbiology and Applied Sciences, 6(3), 164-173.

Korkut Owen, F., \& Bugay, A. (2014). İletişim becerileri ölçeği'nin geliştirilmesi: Geçerlilik ve güvenilirlik çalışması. Mersin Üniversitesi Eğitim Fakültesi Dergisi, 10(2), 51-64.

Merriam, S. B. (2013). Nitel araştırma: Desen ve uygulama için bir rehber. Ankara: Nobel Yayın Dağıtım.

Miles, M. B., \& Huberman, A. M. (1994). Qualitative data analysis: An expanded Sourcebook. (2nd edition). Thousand Oaks, CA: Sage.

Ministry of Education (2018). Science and technology curriculum. Ankara: Board of Education and Discipline. 


\section{Acta Educationis Generalis \\ Volume 12, 2022, Issue 1}

Nakiboğlu, C. (2001). The teaching of "The Nature of Matter" to chemistry prospective teachers by using Cooperative Learning: effect on achievement of student. G. Ü. Gazi Eğitim Fakültesi Dergisi, 21(3), 131-143.

Nhu, L. T. S. (1999). A case study of cooperative learning in inorganic chemistry tutorials at the Vietnam national university (Master's thesis). Ho Chi Minh City: Ho Chi Minh Comprehensive University.

Novotná, J., Verbovanec, L., \& Török, L. (2013). Creativity and motivation in higher education teacher training. Acta Technologica Dubnicae, 3(1), 1-23. https://doi.org/10.1515/atd-20150023

Önen, F., Demir, S., \& Şahin, F. (2012). Fen öğretmen adaylarının oyunlara ilişkin görüşleri ve hazırladıkları oyunların değerlendirilmesi. Ahi Evran Üniversitesi Kırşehir Eğitim Fakültesi Dergisi (KEFAD), 13(3) 299-318.

Ören, F. Ş., \& Erduran Avc1, D. (2004). Eğitimsel oyunla öğretimin Fen Bilgisi dersi "Güneş sistemi ve Gezegenler" konusunda akademik başarı üzerine etkisi. Ondokuz Mayls Üniversitesi Eğitim Fakültesi Dergisi, 18, 67-76.

Öz Pektaş, H. (2017). Traditional children games in modern education. The Journal of International Social Research, 10(49).

Ün Açıkgöz, K. (2008). Aktif ögrenme. İstanbul: Biliş Yayınları.

Patton, M. Q. (2002). Qualitative research and evaluation methods (3rd edition). Thousand Oaks: Calif Sage Publications, Inc.

Peker, E. A., \& Yalçın, M. (2019). 8. sınıf “enerji kaynakları ve geri dönüşüm” konusu öğretiminde jigsaw tekniğinin etkileri. The Journal of International Lingual Social and Educational Sciences 5(1), 54-74.

Perkins, D. V, \& Saris, R. N. (2001). A "jigsaw classroom” technique for undergraduate statistics courses. Teaching of Psychology, 28, 111-113.

Prastyo, Y. D. (2017). Effects of cooperative learning on student teachers' communicative competence in Indonesia (Unpublished doctoral thesis). Ireland: University of Limerick.

Rosas, R., Nussbaum, M., Cumsille, P., Marianov, V., Correa, M., Patricia, F., Valeska, G., Francisca, L., Ximena, L., Veronica, L., Patricio, R., \& Marcela S. (2003). Beyond Nintendo: Design and assessment of educational video games for first and second grade students. Computers \& Education, 40, 71-94.

Rossman, G., \& Rallis, S. (2003). Learning in the field: An introduction to qualitative research. Thousand Oaks, CA: Sage.

Salomon, G., \& Globerson, T. (1989). When teams do not function the way they ought to international. Journal of Educational Research, 13, 89-99.

Sarıgöz, O. (2017). An analytical study on views of teacher candidates about cooperative learning approach. The Journal of International Social Research, 10(49), 491-497.

Savaş, E., \& Gülüm, K. (2014). Geleneksel oyunlarla öğretim yöntemi uygulamasının başarı ve kalıc1lı üzerine etkisi. Trakya Üniversitesi Sosyal Bilimler Dergisi, 16(1), 183-202.

Senemoğlu, N. (2010). Gelişim öğrenme ve ögrretim kuramdan uygulamaya. Ankara: Gazi Kitapevi.

Seyhan, A., \& Șimșek, Ü. (2019). The effect of jigsaw method on students' attitude towards history course and students' views on the method. Kırşehir Eğitim Fakültesi Dergisi (KEFAD), 20, 631-672.

Sharan, S. (1980). Cooperative learning in small groups: Recent methods and effects on achievement, attitudes and ethnic relations. Review of Educational Research, 50(2), 241-271.

Sharan, S., \& Hertz-Lazarowitz, R. (1980). A group-investigation method of cooperative learning in the classroom. In S. Sharan, P. Hare, C. Webb, \& R. Hertz-Lazarowitz (Eds.), Cooperation in education. Provo, UT: Brigham Young Univ. Press.

Slavin, R. E. (1980). Cooperative learning. Review of Educational Research, 50(2), 315-342.

Slavin, R. E. (1986). Using student team learning (3rd edition). Baltimore, Maryland: The Johns Hopkins University. 


\section{Acta Educationis Generalis \\ Volume 12, 2022, Issue 1}

Slavin, R. E. (1990). Cooperative learning: Theory, research, and practice (Vol. 14). Boston: Allyn and Bacon.

Henderson, T. L., \& Martin, K. (2002). Cooperative learning as one approach to teaching family law. Family Law, 51, 351-360.

Slavin, R. E. (2014). Cooperative learning and academic achievement: Why does group work work? Anales De Psicología, 30(3), 785-791.

Stahl, R. (1994). Cooperative learning in social studies: A handbook for teachers. Menlo Park, CA: Addison-Wesley.

Souvignier, E., \& Kronenberger, J. (2007). Cooperative learning in third graders' jigsaw groups for mathematics and science with and without questioning training. British Journal of Educational Psychology, 77(4), 755-771.

Sömen, T., \& Akcanca, N. (2018).Tasarlanan eğitsel oyunların değerlendirilmesine yönelik gözlem formu geliştirilmesi. In II. Uluslararası Sinırsız Eğitim ve Araştırma Sempozyumu Bildiri Kitabu (USEAS2018), Tukey (pp. 235-238).

Şimşek, Ü. (2007). Çözeltiler ve Kimyasal Denge konularında uygulanan Jigsaw ve Birlikte Ögrenme tekniklerinin öğrencilerin Maddenin Tanecikli Yapıda ögrenmeleri ve akademik başarıları üzerine etkisi (Doctoral thesis). Atatürk Üniversitesi Fen Bilimleri Enstitüsü.

Şimşek, U., \& Baydar, A. (2019). Impact of jigsaw and teams-games tournaments (TGT) on social studies preservice teachers' epistemological beliefs. International Online Journal of Education and Teaching (IOJET), 6(2), 405-414.

Şimşek, U., Örten, H., Topkaya, Y., \& Yıllar, H. (2014). Sosyal bilgiler öğretmen adaylarının işbirlikli öğrenme teknikleri hakkındaki görüşleri. Türkiye Sosyal Araştırmalar Dergisi, 181(181), 231-258.

Tarhan, L., Ayyildiz, Y., Ogunc, A., \& Acar Sesen, B. (2013). A jigsaw cooperative learning application in elementary science and technology lessons: Physical and chemical changes. Research in Science \& Technological Education, 3(2), 184-203.

Timayi, J. M., Bolaji, C., \& Kajuru, Y. K. (2015). Effects of Jigsaw IV cooperative learning strategy (J4CLS) on academic performance of secondary school students in geometry. International Journal of Mathematics Trends and Technology, 28(1), 12-18.

Tran, V. D., \& Lewis, R. (2012). The effects of Jigsaw Learning on students'attitudes in a Vietnamese higher education classroom. International Journal of Higher Education, 1(2), 920.

Towns, M. H., \& Grant, E. R. (1997). I Believe I will go out of this class actually knowing something: Cooperative learning activities in physical chemistry. Journal of Research in Science Teaching, 34(8), 819-835.

Turaçoğlu, G. (2009). Genel Kimya dersi kimyasal bileşiklerin adlandırllması konusunda jigsaw tekniğinin öğrencilerin akademik başarllarına etkisi (Unpublished Master's thesis). İzmir: Dokuz Eylül Üniversitesi Eğitim Bilimleri Enstitüsü.

Turaçoğlu, İ., Alpat, Ş., \& Ellez, A. M. (2013). Effects of jigsaw on teaching chemical nomenclature. Education and Science, 38(167), 256-272.

Turkmen, H., \& Buyukaltay, D. (2015). Which one is better? Jigsaw II versus Jigsaw IV on the subject of the building blocks of matter and atom. Journal of Education in Science, Environment and Health (JESEH), 1(2), 88-94.

Tuzcuoğlu, N., Güven, G., \& Efe, K. (2006). 4-6 yaş grubu çocuklarında oyuncak tercihlerini etkileyen faktörlerin incelenmesi. 1. Uluslar Arası Okul Öncesi Ĕgitim Kongresi, 1, 455-474.

Usta, N., Işık, A., Şahan, G., Genç, S., Taş, F., Gülay, G., Diril, F., Demir, Ö., \& Küçük, K. (2017). The opinions of pre-service teachers on the usage of games in mathematics teaching. International Journal of Social Sciences and Education Research, 3(1), 328-344.

Uyanık, G. (2016). Birleştirme tekniğine dayalı fen bilimleri öğretiminin tutum akademik başarı ve kalıc1lı̆̆a etkisi. e-Kafkas Ĕgitim Araştırmaları Dergisi, 3(2), 23-31.

Ün Açıkgöz, K. (2008). Aktif öğrenme. İstanbul: Biliş Gelişimin Coşkusu. 


\section{Acta Educationis Generalis \\ Volume 12, 2022, Issue 1}

Y1ldırım, A., \& Simsek, H. (2011). Sosyal bilimlerde nitel arastirma yöntemleri (8th edition). Ankara: Seckin Yayinevi.

Yıldız, E., Şimşek, Ü., \& Ağdaş, H.(2017). Eğitsel oyun entegre edilmiş işbirlikli öğrenme modelinin öğrencilerin fen öğrenimi motivasyonları ve sosyal becerileri üzerine etkisi. Ahi Evran Üniversitesi Kırşehir Ë̆itim Fakültesi Dergisi (KEFAD), 18(2), 37-54. 